\title{
BIOCHEMICAL STUDIES OF AMYLASES IN THE SILKWORM, BOMBYX MORI L.: COMPARATIVE ANALYSIS IN DIAPAUSING AND NONDIAPAUSING STRAINS
}

\author{
E. G. Abraham, J. Nagaraju* and R. K. Datta \\ Central Sericultural Research and Training Institute, Srirampura, Mysore-570008, India
}

(Received 9 January 1992; revised and accepted 6 July 1992)

\begin{abstract}
Different amylase enzymes were identified by analysis of digestive fluid and haemolymph in diapausing and nondiapausing strains of silkworm, Bombyx mori. The diapausing strain showed negligible digestive amylase activity at a $\mathrm{pH}$ range of 3-11, while the nondiapausing strain registered strikingly higher amylase activity at $\mathrm{pH}$ 9.2. Higher levels of undigested starch was found in the faecal matter of the diapausing strain, which is consistent with the negligible digestive amylase activity. Developmental specific expression of haemolymph amylase activity was seen in nondiapausing and diapausing strains. In the nondiapausing strain the digestive amylase activity was at its peak during intermoult and depressed during moult. PAGE analysis revealed the occurrence of only anodal digestive and haemolymph amylases in the diapausing strain, whereas both cathodal and anodal enzymes were seen in the digestive fluid and haemolymph of the nondiapausing strain.
\end{abstract}

Key Word Index: amylase; pH optimum; developmental pattern; diapausing and nondiapausing strains; Bombyx mori

\section{INTRODUCTION}

Amylase is one of the key enzymes involved in digestion and carbohydrate metabolism in insects (Daone et al., 1975; Buonocore et al., 1976; Horie and Watanabe, 1980). Amylase enzymes from different origins have been characterized (Fisher and Stein, 1960; Takagi et al., 1971; Baker, 1983, 1987, 1991). In the silkworm, Bombyx mori Yokoyama (1959) reported the presence of two types of amylase activities in digestive fluid and haemolymph. Kanakatsu (1972) purified amylase of the digestive fluid and studied its properties (Kanakatsu, 1978). Silkworm strains of tropical countries like India lay nondiapausing eggs, breed throughout the year (polyvoltine) and are endowed with high survival rate, short larval span and small quantity of silk fibre, while those of temperate countries like Japan lay diapausing eggs, undergo two generations in a year (bivoltine), secrete longer silk fibre but have poor survival rate under tropical conditions (Tazima, 1991; Murakami, 1989). Biochemical differences between diapausing and nondiapausing strains are not well understood although such differences do exist (Gamo, 1983).

\section{MATERIALS AND METHODS}

Silkworms and collection of samples

The silkworm strains used for the present study are Nistari, an indigenous polyvoltine strain known to have been introduced to India almost $500 \mathrm{yr}$ ago (Mukherjee, 1919) and $\mathrm{NB}_{1}$, an inbred line derived from a Japanese

*Author for correspondence. hybrid. Characteristics of these two strains are given in Table 1. Larvae were fed on fresh mulberry leaves of Morus alba four times a day except during moult.

Haemolymph was collected every day from the first day of the fourth larval stadium up to the third day after onset of spinning. Samples were obtained by cutting the last abdominal leg and were collected in precooled tubes containing a few crystals of phenylthiourea. Digestive fluid was collected every day from the first day of the fourth larval stadium up to the onset of spinning. Larvae were starved for $4 \mathrm{~h}$ and made to vomit by brief exposure to chloroform vapours. During moulting digestive juice was collected from midguts after dissection of larvae. Digestive fluid was collected into precooled tubes. Five individual larvae were used for sample collection. Since the sex was not discernible during the larval stage, it is probable that the samples were derived from both sexes. Both digestive and haemolymph samples were centrifuged at $10,000 \mathrm{rpm}$ for $10 \mathrm{~min}$ to remove undigested leaf particles and haemocytes respectively and stored at $-20^{\circ} \mathrm{C}$ until use.

\section{Enzyme assay}

Amylase activity was measured with the dinitrosalicylic acid procedure using soluble starch as substrate (Bernfeld, 1955; Baker, 1991). Briefly, $20 \mu 1$ haemolymph was incubated in $1.5 \mathrm{ml}$ of $20 \mathrm{mM}$ phosphate buffer (pH 6.8) containing $0.2 \%$ soluble starch and $1 \mathrm{mM} \mathrm{CaCl}{ }_{2}$ at $37^{\circ} \mathrm{C}$ for $30 \mathrm{~min}$. Released maltodextrins were estimated by boiling with $2 \mathrm{ml}$ dinitrosalicylic acid solution for $10 \mathrm{~min}$ and by measuring the absorbance at $525 \mathrm{~nm}$. For controls enzyme was added after the addition of dinitrosalicylic acid. For digestive fluid enzyme assay conditions were the same as described previously except for the incubation buffer which was $10 \mathrm{mM}$ borate $(\mathrm{pH} 9.2)$. Maltose was used as a standard and the enzyme activity was expressed as $\mathrm{mg}$ of maltose released $/ \mathrm{ml} / \mathrm{min}$ at $37^{\circ} \mathrm{C}$. Samples were diluted prior to assay to maintain linearity. Assays were carried out for five individual larval samples calibrated against controls for two 
Table 1. Difference in the characteristics of silkworm strains, Nistari (nondiapausing) and $\mathrm{NB}_{1}$ (diapausing) used in

\begin{tabular}{|c|c|c|c|c|c|c|c|}
\hline & Voltinism & $\begin{array}{c}\text { Larval } \\
\text { span } \\
\text { (days) }\end{array}$ & $\begin{array}{c}\text { Single } \\
\text { cocoon } \\
\text { weight } \\
(\mathrm{g})\end{array}$ & $\begin{array}{c}\text { Single } \\
\text { shell } \\
\text { weight } \\
(\mathrm{g})\end{array}$ & $\begin{array}{l}\text { Silk } \\
\text { filament } \\
\text { length } \\
\text { (m) }\end{array}$ & $\begin{array}{l}\text { Cocoon } \\
\text { colour }\end{array}$ & $\begin{array}{c}\text { Cocoon } \\
\text { shape }\end{array}$ \\
\hline Nistari & Polyvoltine & 22 & 1.05 & 0.120 & 420 & Golden & Spindle \\
\hline $\mathrm{NB}_{1}$ & Bivoltine & 24 & 1.90 & 0.430 & 1200 & White & Oval \\
\hline
\end{tabular}

trials and means of all the five values and trials were taken as the final values.

\section{pH optimum}

The effect of $\mathrm{pH}$ was determined using buffer $(0.1 \mathrm{M})$ containing acetate, phosphate, borate and glycine from $\mathrm{pH}$ 3 to 11 and $1 \mathrm{mM} \mathrm{CaCl}$. Enzyme sources were crude haemolymph and digestive fluid. Results are means of values of two sets with duplicates at each $\mathrm{pH}$.

\section{Electrophoresis}

Haemolymph from fifth day of fifth stadium larvae were separated on $7.5 \%$ polyacrylamide gel electrophoresis (PAGE) (Gabriel, 1971). After the run, the gel was washed and incubated in $20 \mathrm{mM}$ phosphate buffer ( $\mathrm{pH} 6.8$ ) containing $0.5 \%$ soluble starch and $1 \mathrm{mM} \mathrm{CaCl}{ }_{2}$ at $37^{\circ} \mathrm{C}$ for $45 \mathrm{~min}$ and stained with $\mathrm{KI}-\mathrm{I}_{2}$ solution (Baker, 1989). Digestive fluid was separated on $7.5 \%$ PAGE using a discontinuous buffer system (Gabriel, 1971) and amylase zymograms were made as described above except that the incubation buffer was $10 \mathrm{mM}$ sodium borate (pH 9.2). Cathodal isozymes were separated by reversing the polarity of the current Electrophoresis was carried out at constant voltage $(100 \mathrm{~V})$ for $5 \mathrm{~h}$ at $5^{\circ} \mathrm{C}$

\section{Estimation of starch}

Faecal matter of fourth day of fifth stadium larvae was collected (from a group of hundred larvae) and dried in a hot air oven. Starch was extracted with perchloric acid, precipitated with iodine and the recovered starch was hydrolysed and determined as glucose (Hasid and Abraham, 1957).

\section{RESULTS}

\section{Effect of $\mathrm{pH}$ on amylase activity}

Haemolymph amylase of both nondiapausing and diapausing strains was most active at $\mathrm{pH} 6.8$ (Fig. 1) while that of digestive fluid of the nondiapausing strain showed the highest activity at $\mathrm{pH} 9.2$ (Fig. 1).

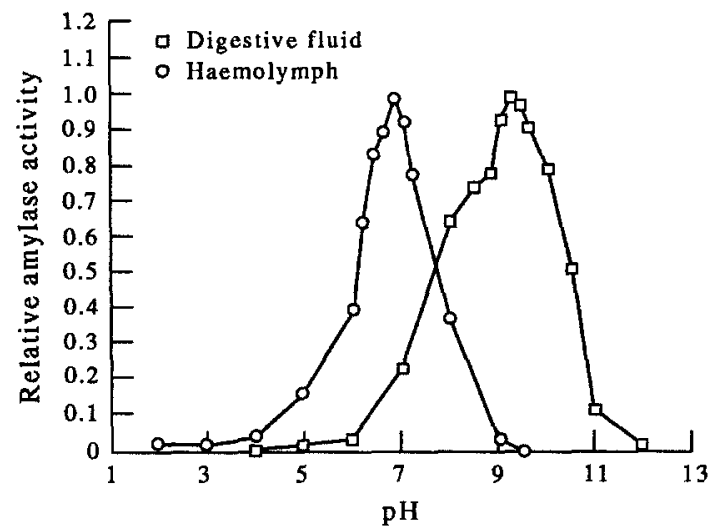

Fig. 1. Effect of $\mathrm{pH}$ on amylase activity in haemolymph $(O)$ and digestive fluid $(\square)$ of Bombyx mori. Values are mean of two tests with duplicates at each $\mathrm{pH}$.
There was a shoulder of activity in the region between $\mathrm{pH} 8.5$ and 9.0 which probably indicates that the isozymes may not all have the same $\mathrm{pH}$ optima. The digestive fluid of the diapausing strain did not show any discernible enzyme activity or peak at any $\mathrm{pH}$ in the range of 3-11.

\section{Developmental pattern of haemolymph amylase}

The amylase activity in the haemolymph of Nistari and $\mathrm{NB}_{1}$ silkworm strains was determined from the first day of the fourth larval stadium to the third day of spinning. Results show that in both the strains the enzyme activity registered a steep increase during larval development (Figs 2 and 3). The activity reached maximum on the third day in $\mathbf{N B}_{1}$ and the fourth day in Nistari, in the fourth larval stadium (Fig. 3) and maintained a steady level until ecdysis. During moult a noticeable depression in enzyme activity was observed. Enzyme activity increased on resumption of feeding after the fourth ecdysis and showed maximum activity on the fourth day followed by a decline towards the end of spinning. On the second day of spinning, enzyme activity was depressed but registered a spurt of activity at the larval ecdysis stage. Although both Nistari and $\mathrm{NB}_{1}$ registered almost similar patterns of enzyme activity during larval development, the latter showed a higher level of enzyme activity throughout larval development except on second day of spinning.

\section{Developmental pattern of digestive fluid amylase}

Digestive fluid amylase activity in both $\mathbf{N B}_{1}$ and Nistari was determined from the first day of the fourth larval stadium to the onset of spinning. A striking difference in enzyme activity was observed between the two strains (Figs 2 and 3). Digestive amylase activity of Nistari was 40 -fold higher than that of haemolymph. The enzyme activity was found to be low during the third moult, but increased to 23 units on the fourth day of the fourth larval stadium and dropped to as low as 7 units during the fourth moult followed by an increase after the fourth ecdysis (Fig. 2). At the fifth larval stadium, during which the silkworm registers maximum growth, the enzyme showed maximum activity (42 units) on the fourth day followed by a decrease towards the onset of spinning. The amylase activity in the digestive fluid of $\mathrm{NB}_{1}$ strain was found to be negligible (Fig. 3). The maximum enzyme activity recorded was only 0.1 unit on the sixth day of the fifth instar which is 400 -fold less than that of Nistari digestive fluid.

\section{Electrophoretic profiles}

Crude haemolymph and digestive fluid samples from day 5 of the fifth stadium larvae were separated on vertical PAGE with a discontinuous buffer system. 


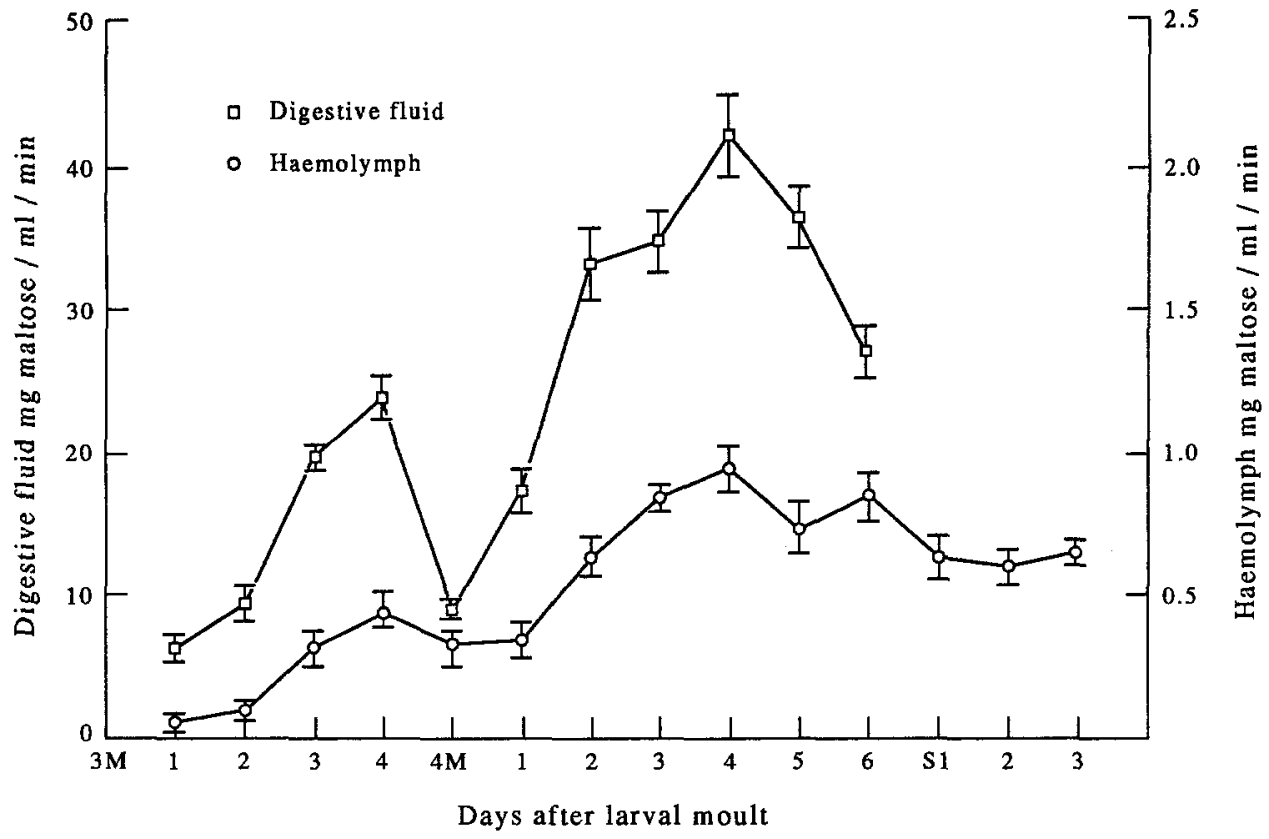

Fig. 2. Amylase activity in the digestive fluid $(\square)$ and haemolymph $(O)$ of the nondiapausing strain, Nistari during different developmental stages. 3M: third larval moult; $4 \mathrm{M}$ : fourth larval moult; S: spinning. Enzyme activity is expressed as $\mathrm{mg}$ of maltose released $/ \mathrm{ml} / \mathrm{min}$. Each point is the mean of five individuals in two replicates. Error bars indicate standard deviations of means.

The preliminary electrophoretic screening of haemolymph and digestive fluid samples collected from a large number of such larvae did not reveal any difference between individuals (data not shown). Hence, pooled samples of mixed sexes were used for electrophoretic analysis.
The haemolymph amylase enzyme migrated towards the anode as four bands in the nondiapausing strain and five bands in the diapausing strain [Fig. 4(A), lanes 1 and 2]. Except for the slow migrating band in the diapausing strain [Fig. 4(A), lane 2], the remaining four bands were of the same

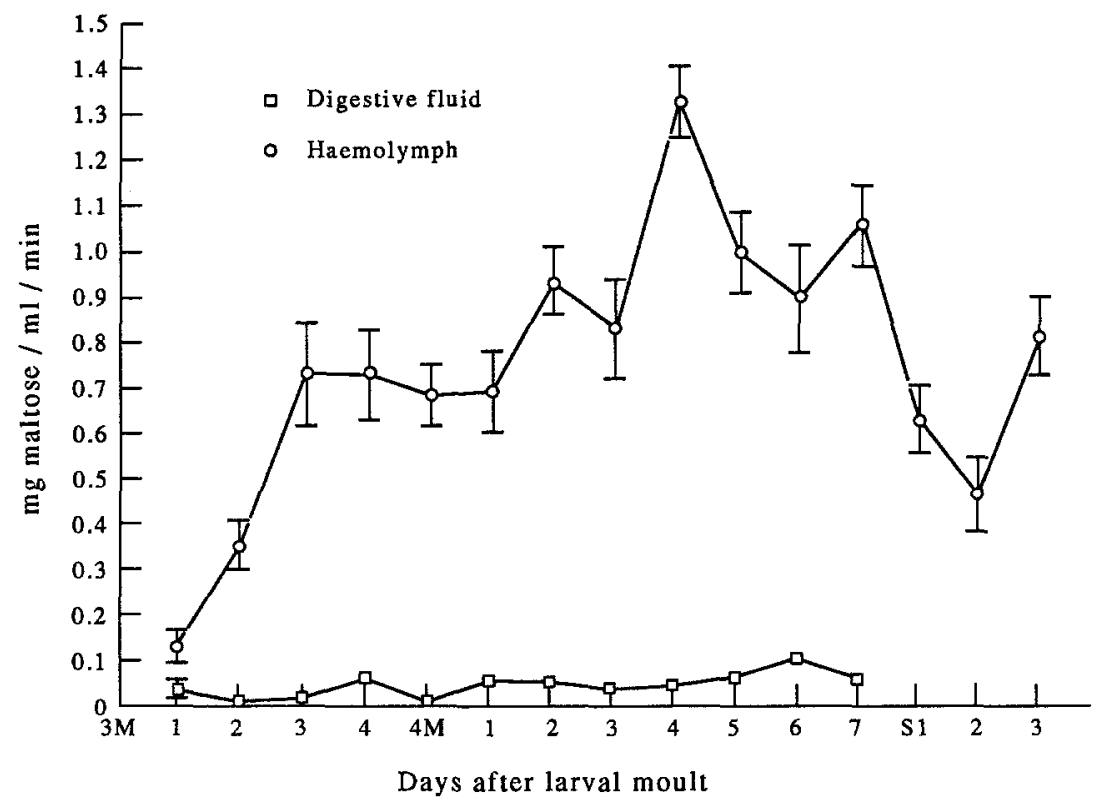

Fig. 3. Amylase activity in the digestive fluid $(\square)$ and haemolymph $(O)$ of the diapausing strain $N_{1}$ during different developmental stages. 3M: third larval moult; 4M: fourth larval moult; S: spinning enzyme activity expressed as $\mathrm{mg}$ maltose released $/ \mathrm{ml} / \mathrm{min}$. Each point is the mean of five individuals in two replicates. Error bars indicate standard deviations of means. (Error bars are too small to show around the point for the digestive fluid.) 
mobility in both strains. Electrophoretic separation of haemolymph towards the cathode revealed a unique band [Fig. 4(B), lane 1] in the nondiapausing strain, which was not detected in the diapausing strain [Fig. 4(B), lane 2].

Electrophoretic analysis of digestive fluid shows that the bulk of the amylase activity in Nistari migrated towards the cathode at $\mathrm{pH} 8.8$ as four bands, of which the most intense one migrated faster than the rest [Fig. 5(A), lanes 1-3]. NB $_{1}$ digestive fluid did not show any cathodal amylase activity [Fig. 5(A), lane 4]. However, in the undiluted samples of both the strains an anodal band of relatively low intensity was detected [Fig. 5(B), lanes 3 and 4] which was not discernible in the diluted samples [Fig. 5(B), lanes 1 and 2]. In order to check the possibility that some of the isozymes observed in the digestive fluid samples are derived from mulberry leaf, leaves were extracted separately in $100 \mathrm{mM}$ Tris $\mathrm{pH} 9$ with $150 \mathrm{mM} \mathrm{NaCl}$ and run on PAGE and stained for amylase activity. We did not observe any anodal or cathodal amylase activity which could be attributed to mulberry leaf.

\section{Starch content in the faecal matter}

To understand whether the striking difference in amylase activity observed in the digestive fluid of diapausing and nondiapausing strains is manifested in the digestion of starch, faecal matter of fourth day fifth stadium larvae was extracted and analysed for starch content. The results showed that the diapausing strain excreted 5-fold more starch than the nondiapausing strain (Fig. 6).

\section{DISCUSSION}

The maximum amylase activity at pH 6.8 observed in the haemolymph in the present study is consistent

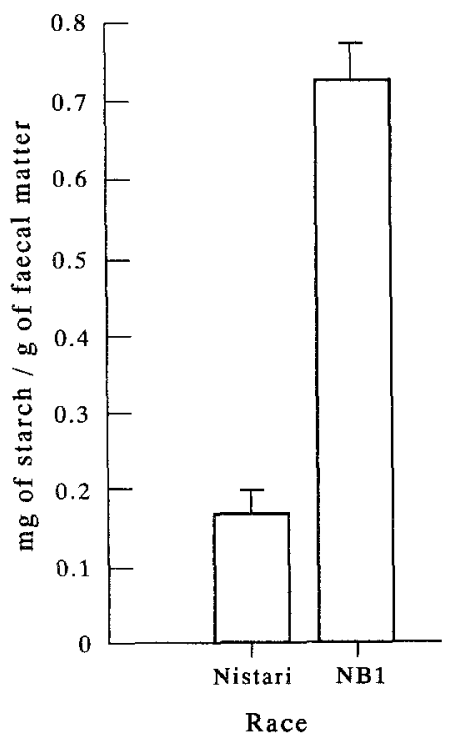

Fig. 6. Starch content in the faecal matter of diapausing strain $\mathrm{NB}_{1}$ and nondiapausing strain, Nistari. Values are expressed as $\mathrm{mg} / \mathrm{g}$ dry wt of faecal matter. Error bars indicate the standard deviation of means for five determinations. with the physiological $\mathrm{pH}$ of the haemolymph as reported by Wyatt (1961). The optimum $\mathrm{pH}$ of 6.8 of haemolymph amylase observed in the present study is in contrast to slightly acidic range reported in a variety of insect species (Baker, 1987; Podoler and Applebaum, 1971; Buonocore et al., 1976). The sharp ascending and descending nature of the amylase activity indicate that the haemolymph amylase isozymes have similar $\mathrm{pH}$ optima.

Although digestive fluid of diapausing strain did not reveal amylase activity in $\mathrm{pH}$ range of 3-11 (in the spectrophotometric assay), the faint anodal band detected in the zymogram [Fig. 5(B), lane 3] incubated at $\mathrm{pH} 9.2$, indicates that the $\mathrm{pH}$ optima of the anodal amylase probably falls in the alkaline range. The $9.2 \mathrm{pH}$ optima for digestive amylase of nondiapausing strain detected in the present study is in agreement with the observation that the high $\mathrm{pH}$ optima for digestive enzymes are characteristic features in phytophagous lepidopteran larvae (Ito et al., 1962; House, 1974; Eguchi and Iwamoto, 1976) and in other insects (Baker, 1989; Ishaya et al., 1971; Kusano and Tanabe, 1986: Santos et al., 1986). Thus it is clear that the amylase enzymes of haemolymph and digestive fluid have different $\mathrm{pH}$ optima, one in the neutral and the other in the alkaline range.

A unique cathodal amylase isozyme was detected in the haemolymph of the nondiapausing strain in addition to the anodal ones, while the diapausing strain revealed only anodic isozymes. The anodic isozyme detected in the present study is similar to the one reported by Banno et al. (1984) in the haemolymph of day 5 of the fifth stadium larvae of a diapausing strain.

The electrophoretic pattern of digestive amylase in the diapausing and nondiapausing strains confirms the differences. The amylase activity migrated as four closely spaced cathodal bands in the nondiapausing strain, while the diapausing strain did not reveal any such activity. The anodic digestive and haemolymph amylases, although very low in activity, were ubiquitous in almost all the diapausing and nondiapausing strains. On the other hand, the cathodic digestive and haemolymph amylases were found only in the geographically distinct populations of nondiapausing strains (polyvoltine) (data not shown). The cathodal amylase enzyme in the digestive fluid has been purified from the silkworm and has been found to have subunit molecular weight of $55 \mathrm{kDa}$ (Kanakatsu, 1978). The cathodal amylase banding pattern observed in the nondiapausing strain resembles that of Drosophila hydei (Doane et al., 1975), chicken (Lerner and Malacinski, 1975) and human (Karn and Rosenblum, 1975). Karn and Rosenblum (1975) have convincingly demonstrated in humans that the amylase isozyme heterogeneity is due to deamidation, a post translational modification. It is possible that the multimeric forms of the cathodal amylase isozyme observed in the digestive fluid of nondiapausing strain may be the result of post translational modifications such as deamidation or could be a multimeric form of the same polypeptide.

The increased enzyme activity and efficient starch digestion may have adaptive significance in the nondiapausing strain which is known to survive better under tropical condition than the diapausing strains 


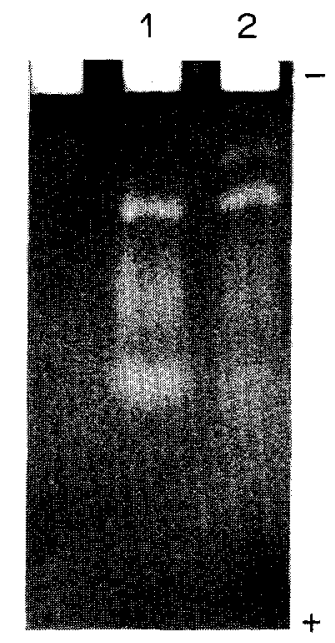

A

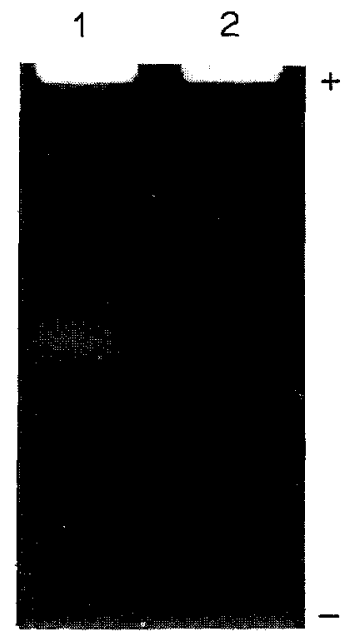

B

Fig. 4. Vertical PAGE $(\mathrm{pH} 8.8)$ of crude haemolymph samples stained for amylase activity with $\mathrm{KI}-\mathrm{I}_{2}$ solution after incubation with $0.5 \%$ starch. (A) Anodal bands. Lane 1: $20 \mu 1$ haemolymph of nondiapausing strain Nistari; lane 2: $20 \mu \mathrm{l}$ haemolymph of diapausing strain $\mathrm{NB}_{1}$. (B) Cathodal bands. Lane 1: $20 \mu \mathrm{l}$ haemolymph of nondiapausing strain Nistari; lane 2: $20 \mu 1$ haemolymph of diapausing strain $\mathrm{NB}_{1}$.

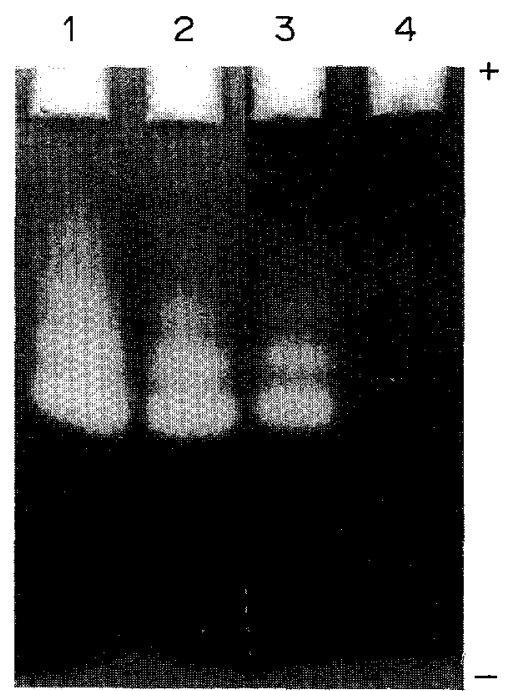

A

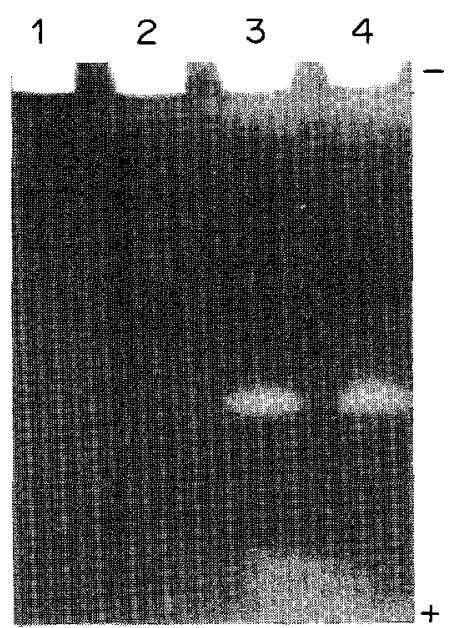

B

Fig. 5. Vertical PAGE (pH 8.8) of crude digestive fluid samples stained for amylase activity with KI-I solution after incubation with $0.5 \%$ starch. (A) Cathodal bands. Lanes $1-3$ are $10 \mu 1$ each of $10 \times, 20 \times$, and $40 \times$ diluted digestive fluid of nondiapausing strain Nistari; lane 4:20 $\mu \mathrm{l}$ of undiluted digestive fluid of diapausing strain $\mathrm{NB}_{1}$. (B) Anodal bands. Lanes I and 2 are $10 \times$ diluted digestive fluid of Nistari and $\mathrm{NB}_{1}$; lanes 3 and 4 are $10 \mu \mathrm{l}$ each of undiluted samples of digestive fluid of $\mathrm{NB}_{1}$ and Nistari. 

(Murakami, 1989). The effectiveness of amylases in survival has been reported in insect species such as Tenebrio molitor (Buonocore et al., 1976). Since digestibility of starch in diapausing and nondiapausing strains is quite different, the starch content in artificial diet could be manipulated to study the quantitative relationship of digestive amylase and starch content with respect to larval growth and survival.

The function of haemolymph amylase is not fully understood although Wyatt (1967) suggested its possible involvement in the degradation of fat body glycogen. The presence of this enzyme in abundance during larval development in both diapausing and nondiapausing strains imply that this enzyme has some important physiological role. The developmental regulation of the digestive amylase and the expression of cathodal forms only in the nondiapausing strains make digestive amylase an interesting candidate for the study of its molecular biology.

Acknowledgements - The authors acknowledge the financial assistance from the Department of Biotechnology, Government of India, and the Central Silk Board, Bangalore.

\section{REFERENCES}

Baker J. E. (1983) Properties of amylases from midguts of larvae of Sitophilus granarius. Insect Biochem. 13, 421-428.

Baker J. E. (1987) Purification of isoamylases from the rice weevil Sitophilus oryzae (L.) (Coleoptera:Curculionidae), by high performance liquid chromatography and their interaction with partially purified amylase inhibitors from wheat. Insect Biochem. 17, 37-44.

Baker J. E. (1989) Interaction of partially purified amylases from larvae Anagasta Kuehniella (Lepidoptera:Pyralidae) with amylase inhibitors from wheat. Comp. Biochem. Physiol. 93B, 239-246.

Baker J. E. (1991) Purification and partial characterisation of amylase allozymes from the lesser grain borer, Rhyzopertha dominica. Insect Biochem. 21, 303-311.

Banno Y., Kawaguchi Y. and Doira H. (1984) Sexual dimorphism and developmental changes in haemolymph amylase of Bombyx mori. J. Sericult. sci. Jpn 53, 335-340.

Bernfeld P. (1955) Amylases, $\alpha$ and $\beta$. In Methods in Enzymology (Edited by Colowick S. P. and Kaplan N. O.), Vol. 1, pp. 149-158. Academic Press, New York.

Buonocore V., Poerio E., Silano V. and Tomasi M. (1976) Physical and catalytic properties of $\alpha$-amylase from Tenebrio molitor L. larvae. Biochem. J. 153, 621-625.

Daone W. W., Abraham I., Kolar M. M., Martenson R. E. and Deibler G. E. (1975) Purified Drosophila $\alpha$-amylase isozyme. In Isozyme IV (Edited by Martet C. L.), pp. 585-607. Academic Press, New York.

Eguchi M. and Iwamoto A. (1976) Alkaline proteases in the midgut tissue and digestive fiuid of silkworm, Bombyx mori. Insect Biochem. 6, 491-496.

Fisher E. H. and Stein E. A. (1960) $\propto$ Amylases. In The Enzymes (Edited by Boyer P. D., Lardy H. and Myrback K.), 2nd Edn, Vol. 4, pp. 313-343. Academic Press, New York.

Gabriel O. (1971) Analytical disc gel electrophoresis. In Methods in Enzymology (Edited by Joakoby W. B.), Vol. 22, pp. 565-578. Academic Press, New York.
Gamo T. (1983) Biochemical genetics and its application for breeding silkworm. $J A R Q 16,264-272$.

Hasid W. Z. and Abraham S. (1957) Chemical procedures for analysis of polysaccharides. In Methods in Enzymology (Edited by Colowick S. P. and Kaplan N. O.), Vol. III, pp. 34-49. Academic Press, New York.

Horie Y. and Watanabe H. (1980) Recent advances in Sericulture. Ann. rev. Ent. 25, 49-71.

House H. L. (1974) Digestion. In The Physiology of Insects (Edited by Rockstein M.), 2nd Edn, Vol. 5, pp. 63-117. Academic Press, New York.

Ishaaya I., Moore I. and Joseph D. (1971) Protease and amylase activity in the larvae of Egyptian cottonworm, Spodoptera litoralis. J. Insect Physiol. 17, 945-953.

Ito T., Mukaiyama F. and Tanaka M. (1962) Some properties of amylase of digestive juice and blood of larvae of silkworm, Bombyx mori L. J. Sericult. sci. Jpn 31, 228-234.

Kanakatsu R. (1972) Purification and some properties of amylase in the digestive juice of silkworm larvae, Bombyx mori. J. Sericult. Sci. Jpn 42, 285-292.

Kanakatsu R. (1978) Studies on further properties for an alkaline amylase in the digestive juice of silkworm, Bombyx mori. J. fac. text. sci. Technol. 76, 1-21.

Karn R. C. and Rosenblum B. B. (1975) Genetic and posttranslational mechanism determining human amylase isozyme heterogeneity. In Isozyme IV, Genetics and Evolution (Edited by Martet C. L.), Vol. 4, pp. 745-776. Academic Press, New York.

Kusano T. and Tanabe S. (1986) Enzymatic properties of the midgut amylase activity and its changes during development in the cabbage armyworm, Mammestra brassicae L. Kontyu (Tokyo) 54, 12-24.

Lerner L. M. and Malacinski G. M. (1975) Genetics and structural studies of chicken $\alpha$-amylase isozyme and their modified forms, and structural studies of HOG amylase. In Isozymes, IV Genetics and Evolution (Edited by Markert C. L.), pp. 727-743. Academic Press, New York. Mukherjee N. G. (1919) Handbook of Sericulture. Government Book Department, Calcutta, India.

Murakami A. (1989) Genetic studies on tropical races of silkworm (Bombyx mori), with special reference to cross breeding strategy between tropical and temperate races. 2 . Multivoltine silkworms in Japan and their origin. JARO 23, 123-127.

Podoler H. and Applebaum S. W. (1971) The $\alpha$-amylase of beetle, Callosobruchus chinensis. Biochem. J. 121, 321-325.

Santos C. D., Riberio A. S. and Terra W. R. (1986) Differential centrifugation, calcium precipitation, ultrasonic disruption of midgut cells of Erinnys ello caterpillars. Purification of cell microvilli and inference concerning secretory mechanisms. Can. J. Zool. 64, 490-500.

Takagi T., Toda H. and Isemura T. (1971) Bacterial and mold amylases. In The Enzymes (Edited by Boyer P. D.), 3rd Edn, Vol. V, pp. 235-271. Academic Press, New York.

Tazima Y. (1991) A view on the improvement of Mysore breeds. Proceedings on the International Congress of Tropical Sericulture and Practices. 1988, Part IV, pp. 1-5. Bangalore, India.

Wyatt G. R. (1961) The Biochemistry of Insect Haemolymph. A. rev. Ent. 6, 75-102.

Wyatt G. R. (1967) The biochemistry of sugars and polysaccharides in insects. Adv. Insect. Physiol. 4, 287-360.

Yokoyama T. (1959) Silkworm Genetics Illustrated. Japanese society for promotion of science. Ueno Park, Tokyo. 